\title{
Peculiarities of the course of diabetic kidney disease in patients with latent autoimmune diabetes in adults
}

For citation: Mižnarodnij endokrinologìčnij žurnal. 2021;17(2):1 16-120. doi: 10.22141/2224-0721.17.2.2021.230565

\begin{abstract}
Background. Latent autoimmune diabetes in adults ( $L A D A)$ is a heterogeneous type of diabetes mellitus (DM) that combines symptoms of type 1 (T1DM) and type 2 diabetes mellitus (T2DM). Data about the frequency and structure of microvascular complications in LADA are small and quite contradictory, there is almost no information about the peculiarities of their course, which indicates the need for research in this area. Therefore, the purpose of the study was to determine the characteristics of diabetic kidney disease (DKD) in patients with latent autoimmune diabetes in adults compared with classical types of DM. Materials and methods. The study enrolled 112 patients with DM with DKD. Patients were divided into three groups: I - 54 people with LADA, II - 30 patients with T1DM, III - 28 patients with T2DM. Peculiarities of DKD course were studied based on the anamnesis data, clinical examination, glomerular filtration rate (GFR) values, albuminuria, albumin-creatinine ratio. Results. According to the anamnesis the diagnosis of DKD in patients with LADA was established on average 3 years after the manifestation of diabetes, which is 4.5 years earlier than in T1DM but 1.3 years later than in T2DM. The analysis of GFR stages showed that in LADA the category G3 was the most often (63\%) (G3a - in $46 \%$, G3b - in $17 \%)$. The other patients had G1 stage (7\%), G2 stage (24\%), and only $6 \%$ of patients had G4 stage. The albuminuria categories $A 1$ and $A 2$ predominated in patients of all groups (in LADA - 43\% of people in each category), while category $A 3$ in $L A D A$ was registered twice as often as in T1DM. In LADA, the predominant phenotypes were non-albuminuric renal impairment (NARI) (43\%) and albuminuric phenotype (AP) (35\%), in T1DM - AP (50\%) and NARI (40\%), and in T2DM, all three phenotypes were registered with almost the same frequency (AP — in $32 \%, N A R I$ - in $29 \%$, progressive renal decline - in $39 \%$ ). Conclusions. The course of diabetic kidney disease in patients with latent autoimmune diabetes in adults differs from that in the classic types of diabetes, which indicates the need to develop a specific algorithm for this cohort of patients.
\end{abstract}

Keywords: diabetes mellitus; latent autoimmune diabetes in adults; diabetic kidney disease

\section{Introduction}

Latent autoimmune diabetes in adults (LADA) is a heterogeneous type of diabetes mellitus (DM) that combines symptoms of type 1 diabetes mellitus (T1DM) and type 2 diabetes mellitus (T2DM) and is diagnosed by detecting the antibodies to islet antigens in the blood in disease manifestations in adults aged over 35 years [1].

According to the updated classification of the American Diabetes Association (2021), LADA is classified as T1DM, which develops in adulthood and has an indolent course [2]. In 2020, an international expert panel was held to get a consensus on the management of patients with this type of diabetes, who were offered advanced diagnostic features of LADA, namely the age of patients over 30 years; family/personal history of autoimmunity; reduced frequency of metabolic syndrome compared with T2DM - lower indices of insulin resistance, body weight, blood pressure, and dyslipidemia compared with T2DM; no difference in

Для кореспонденції: Царик Ірина Олександрівна, аспірант кафедри клінічної імунології, алергології та ендокринології, Буковинський державний медичний університет, Театральна пл., 2, м. Чернівці, 58002, Україна; е-mail: irynatsaryk13@gmail.com; контактний тел.: +38 (099) 4427694.

For correspondence: Iryna Tsaryk, MD, PhD student at the Department of Clinical Immunology, Allergology and Endocrinology, Bukovinian State Medical University, Teatralna sq., 2, Chernivtsi, 58002, Ukraine; e-mail: irynatsaryk13@gmail.com; contact phone: +38 (099) 4427694.

Full list of author information is available at the end of the article. 
cardiovascular effects for patients with LADA and patients with T2DM; slower decrease in C-peptide levels than in T1DM; the presence of antibodies to glutamic acid decarboxylase as the most sensitive marker (rarely other antibodies - islet cell antibodies, IA-2A Ab, ZnT8A and to tetraspanin 7); no need for insulin therapy at the beginning of diabetes [3].

Diabetic nephropathy is considered one of the main chronic microvascular complications of diabetes mellitus, as well as the leading cause of end-stage chronic kidney disease (CKD) [4, 5].

To cover all types of kidney disease that occur in people with diabetes mellitus, instead of the term "diabetic nephropathy", the term "diabetic kidney disease" (DKD) was proposed in connection with the identification of additional phenotypes of this pathology [6]. Thus, to date, DKD is represented by the albuminuric phenotype (AP), non-albuminuric renal impairment (NARI), and progressive renal decline (PRD). This distribution suggests that the progression of DKD to the terminal stage of CKD in both T1DM and T2DM can occur in two ways: by the mechanisms of progressive growth of albuminuria and isolated decrease in glomerular filtration rate (GFR), respectively [7].

The current results of research on chronic complications of LADA mainly relate to macrovascular lesions [8, 9]. Concerning the microvascular complications, there is evidence in the literature that diabetic retinopathy and DKD in LADA as in T2DM develop almost at the same time after the manifestation of the disease [10]. However, other studies refer to a higher frequency of microalbuminuria (MAU) in T2DM and probably a higher frequency of microvascular complications at the stage of manifestation in T1DM compared to LADA [11]. The authors reported about a relationship between MAU and the age of LADA onset as well as the development of diabetic retinopathy. At the same time, it was found that in patients with LADA and end-stage CKD, the incidence of diabetic retinopathy is lower compared to T1DM, and the incidence of cardiovascular events is lower compared to T2DM [12].

Thus, data about the frequency and structure of microvascular complications in LADA are small and quite contradictory, there is almost no information about the peculiarities of their course, which indicates the need for research in this area.

The purpose of the study was to determine the characteristics of diabetic kidney disease in patients with latent autoimmune diabetes in adults compared with classical types of diabetes.

\section{Materials and methods}

One hundred and twelve patients with DM and DKD who were treated at the Chernivtsi Regional Endocrinology Center were examined (mean age of patients $46.0 \pm 1.2$ years; men -47 , women -65 ; diabetic history $11.40 \pm 0.86$ years). Patients were divided into three groups. The first group included 54 people with LADA, the second group consisted of 30 patients with T1DM, the third -28 patients with T2DM.
The diagnosis of LADA was established based on the recommendations [5]. All patients were tested for two types of antibodies to islet antigens. The antibodies to glutamic acid decarboxylase and tyrosine phosphatase-2A (IA-2A $\mathrm{Ab}$ ) were determined by enzyme-linked immunosorbent assay using kits "DiaMetra S.1.r." (Italy).

Peculiarities of the DKD course were studied based on the anamnesis data, clinical examination, GFR values, albuminuria, etc. [13]. GFR was determined by the formula CKD-EPI according to the recommendations of KDIGO (2012) [14]. The albuminuria category was determined by the indicators of microalbuminuria and the albumin-creatinine ratio (ACR) in the urine using sets of Granum Laboratory Ltd. (Ukraine).

AP of DKD was confirmed at values of ACR $>3 \mathrm{mg} / \mathrm{ml}$, NARI - at GFR $<60 \mathrm{ml} / \mathrm{min} / 1.73 \mathrm{~m}^{2}$ in the absence of albuminuria, PRD - at loss of GFR $\geq 5 \mathrm{ml} / \mathrm{min} / 1.73 \mathrm{~m}^{2} /$ year irrespective of indicators of albuminuria [15].

Proper permission was secured from the Bukovinian State Medical University Ethical Committee (protocol 3, dated 02.06.2020).

Mathematical processing of the data obtained was performed using the programs Primer of Biostatistics, version 5.0 (S. Glantz, USA).

\section{Results}

According to the anamnesis data, the diagnosis of DKD in patients with LADA was established on average 3 years after the manifestation of diabetes mellitus, which significantly differs from the results obtained for T1DM (7.5 years) and slightly differs from T2DM (1.7 years).

The analysis of GFR values by stages showed that in LADA (Fig. 1) the category G3 was the most common (in $63 \%)(\mathrm{G} 3 \mathrm{a}-$ in $46 \%, \mathrm{G} 3 \mathrm{~b}-$ in $17 \%)$. The other patients had the G1 stage ( $7 \%$ ), G2 stage (24\%), and only $6 \%$ of patients had G4 stage. In T1DM, the vast majority of patients had G2 stage (42\%) and G3 stage (40\%). Eighteen percent of patients with T2DM had initial stages of GFR disorders (G1-G2), while $68 \%$ of patients had GFR disorders of stage $\mathrm{G} 3$ (G3a - in $54 \%, \mathrm{G} 3 \mathrm{~b}$ - in $14 \%$ ), and G4 (14\%).

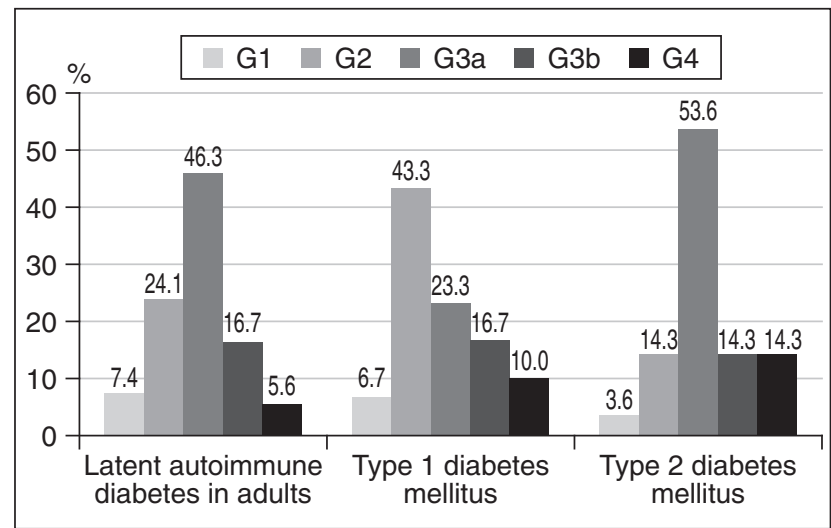

Figure 1. Distribution of patients with different types of diabetes mellitus and diabetic kidney disease by glomerular filtration rate 


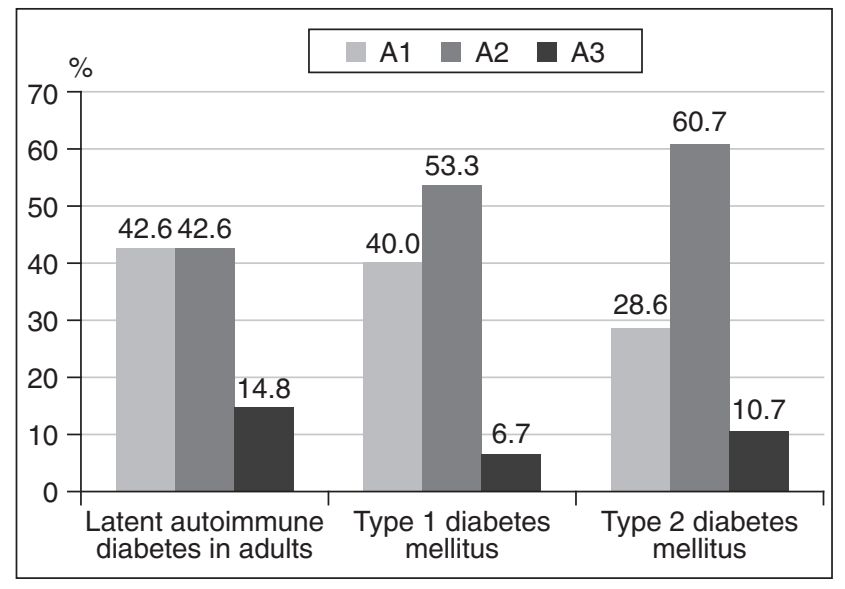

Figure 2. Distribution of patients with different types of diabetes mellitus and diabetic kidney disease by albuminuria categories

The greater number of patients with the initial stages of GFR disorders in T1DM is probably due to timely diagnosis of the underlying disease, and, thus, earlier control, as well as longer development of classic microvascular complications and their slower progression. In contrast, in T2DM, there is a late diagnosis and the involvement of additional pathogenetic mechanisms associated with insulin resistance. At the same time, DKD in LADA, which combines the features of both classic types of diabetes, occupies an intermediate position.

Regarding the features of albuminuria (Fig. 2), the categories A2 (43\% of patients with LADA, $53 \%$ - with T1DM and $61 \%$ - with T2DM) and A1 (about $40 \%$ of patients with LADA and T1DM and almost $30 \%$ of patients with T2DM) dominated in all groups. It should be noted that category A3 was quite rare in all types of diabetes, but it was registered twice more often in LADA (15\%) than in T1DM (7 \%).

When analyzing the course of DKD in groups of patients with different types of diabetes (Fig. 3), it was found that in LADA the predominant phenotypes are NARI (43\%) and AP (35\%), in T1DM - AP (50\%) and NARI (40\%), and in T2DM, all three phenotypes were registered with almost the same frequency (AP - in $32 \%$, NARI - in $29 \%$, PRD - in $39 \%$ patients).

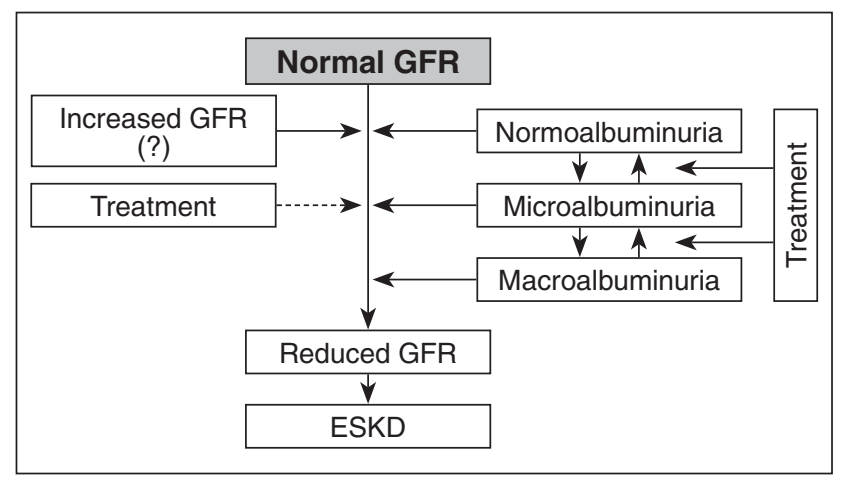

Figure 4. Mechanisms of development and progression of diabetic kidney disease [19]

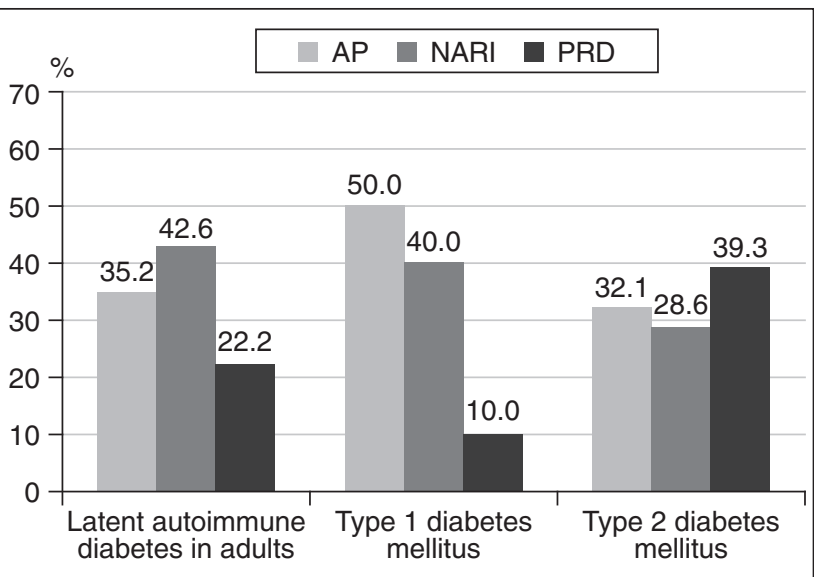

Figure 3. Distribution of patients with different types of diabetes mellitus by phenotypes of diabetic kidney disease

\section{Discussion}

It is known that in patients with T2DM, in contrast to T1DM, the period of establishment of DKD from the onset of diabetes mellitus is shorter due to late diagnosis of the underlying disease because of less pronounced clinical symptoms. For this reason, according to modern standards, it is recommended to screen DKD immediately after the diagnosis of T2DM, while in T1DM -5 years after the manifestation [16].

At the same time, the results of the analysis of all cases of LADA demonstrated that in $28 \%$ of people DKD was diagnosed at the time of diagnosis of diabetes mellitus, in $20 \%$ - after 1 year from the beginning, in $32 \%$ - in the period from 2 to 5 years, in $16 \%$ - after 5-10 years and only in $4 \%$ more than 10 years later.

So, DKD in LADA is diagnosed after the manifestation of the disease much earlier than in T1DM. However, because according to the current classification LADA refers to T1DM, following the recommendations for screening for DKD in T1DM leads to late diagnosis of this chronic complication, and, consequently, to the lack of adequate treatment. All this indicates the necessity for the development of a LADA-specific DKD diagnostic algorithm [17, 18].

The high frequency of NARI in LADA and T1DM in comparison with T2DM attracts attention. It should also be noted that PRD in LADA was registered more than twice as often as in T1DM and almost twice less often than in T2DM, which is probably related to the timing of the diagnosis of DM and the start of appropriate therapy.

Probable mechanisms of development of these phenotypes are presented in Fig. 4 and indicate that the increase in the frequency of NARI contributes to the timely start of treatment of the underlying disease, as well as the emergence of new groups of drugs with nephroprotective effect, which lead to regression of albuminuria.

At present, it is difficult to give clear characteristics and explain the pathophysiological mechanisms of clinical phenotypes of DKD, as the results of studies differ significantly. There is a hypothesis about the predominance of macrovascular and tubulointerstitial lesions in NARI in contrast to 
classical AP with a predominant glomerular lesion, which includes thickening of the glomerular basement membrane, expansion of the mesangium and glomerulosclerosis. Unfortunately, so far this information has not been confirmed histologically. One study of renal biopsies in patients with T2DM and with different DKD phenotypes revealed typical glomerular lesions with or without albuminuria, while half of the non-albuminuric patients had vascular and tubulointerstitial changes [20]. Another study confirmed that glomerular, vascular, and tubulointerstitial changes correlated with GFR loss and were more typical for normoalbuminuria in combination with GFR reduction [21].

Thus, the detection of different phenotypes of DKD can be explained by the difference in morphofunctional changes in each of them. AP is a classic consequence of microvascular disorders and, as the analysis showed, is more typical in T1DM. The emergence of NARI is directly related to the improvement of drug approaches and the emergence of new groups of antidiabetic drugs that allow not only to stop the development of proteinuria but also to regress existing kidney damage. Both genetically determined kidney damage and directly the mechanisms of damage caused by diabetes mellitus, in particular progressive amyloidosis caused by increased secretion of the pancreatic hormone amylin, which is synthesized by $\beta$-cells together with insulin, play an important role in the pathogenesis of PRD.

Due to the incompletely understood pathogenesis of NARI and PRD, these two phenotypes need to be studied more closely to identify possible options for their prevention and treatment.

\section{Conclusions}

1. Diabetic kidney disease in latent autoimmune diabetes in adults is diagnosed much earlier after the manifestation of the disease than in type 1 diabetes mellitus.

2. Among patients with latent autoimmune diabetes in adults and diabetic kidney disease, a decrease in glomerular filtration rate of categories $\mathrm{G} 3$ and below is registered more often (in almost $70 \%$ of cases) than in type 1 diabetes mellitus (in $50 \%$ of cases) but less often than in type 2 diabetes mellitus ( $82 \%$ of people). The albuminuria categories A1 and $\mathrm{A} 2$ were registered with the same frequency and with similar tendencies as in classical types of diabetes mellitus predominate, while category A3 is registered almost twice as often as in classical type 1 diabetes mellitus and exceeds that in type 2 diabetes mellitus.

3. The prevalence of phenotypes of diabetic kidney disease varies depending on the type of diabetes mellitus. In latent autoimmune diabetes in adults and type 1 diabetes mellitus, non-albuminuric renal impairment dominates and occurs more often than in type 2 diabetes mellitus. At the same time, progressive renal decline occurs twice as often as in type 1 diabetes mellitus but much less frequently than in type 2 diabetes mellitus.

4. The identified differences indicate the need to develop a specific algorithm for the management of patients with diabetic kidney disease in latent autoimmune diabetes in adults.

\section{References}

1. Pieralice S, Pozzilli P. Latent Autoimmune Diabetes in Adults: A Review on Clinical Implications and Management. Diabetes Metab J. 2018 Dec;42(6):451-464. doi:10.4093/dmj.2018.0190.

2. American Diabetes Association. 2. Classification and Diagnosis of Diabetes: Standards of Medical Care in Diabetes-2021. Diabetes Care. 2021 Jan;44(Suppl 1):S15-S33. doi:10.2337/dc21-S002.

3. Mishra R, Hodge KM, Cousminer DL, Leslie RD, Grant SFA. A Global Perspective of Latent Autoimmune Diabetes in Adults. Trends Endocrinol Metab. 2018 Sep;29(9):638-650. doi:10.1016/j. tem.2018.07.001.

4. Hawa MI, Kolb H, Schloot N, et al; Action LADA consortium. Adult-onset autoimmune diabetes in Europe is prevalent with a broad clinical phenotype: Action LADA 7. Diabetes Care. 2013 Apr;36(4):908-13. doi:10.2337/dc12-0931.

5. Buzzetti R, Tuomi T, Mauricio D, et al. Management of Latent Autoimmune Diabetes in Adults: A Consensus Statement From an International Expert Panel. Diabetes. 2020 Oct;69(10):2037-2047. doi:10.2337/dbi20-0017.

6. Fu H, Liu S, Bastacky SI, Wang X, Tian XJ, Zhou D. Diabetic kidney diseases revisited: A new perspective for a new era. Mol Metab. 2019 Dec;30:250-263. doi:10.1016/j.molmet.2019.10.005.

7. Jiang G, Luk AOY, Tam CHT, et al; Hong Kong Diabetes Register TRS Study Group. Progression of diabetic kidney disease and trajectory of kidney function decline in Chinese patients with Type 2 diabetes. Kidney Int. 2019 Jan;95(1):178-187. doi:10.1016/j. kint.2018.08.026.

8. Maddaloni E, Lessan N, Al Tikriti A, Buzzetti R, Pozzilli P, Barakat MT. Latent Autoimmune Diabetes in Adults in the United Arab Emirates: Clinical Features and Factors Related to Insulin-Requirement. PLoS One. 2015 Aug 7;10(8):e0131837. doi:10.1371/ journal.pone.0131837.

9. Carlsson S. Etiology and Pathogenesis of Latent Autoimmune Diabetes in Adults (LADA) Compared to Type 2 Diabetes. Front Physiol. 2019 Mar 26;10:320. doi:10.3389/fphys.2019.00320.

10. Doshi SM, Friedman AN. Diagnosis and Management of Type 2 Diabetic Kidney Disease. Clin J Am Soc Nephrol. 2017 Aug 7;12(8):1366-1373. doi:10.2215/CJN.11111016.

11. Pugliese G. Updating the natural history of diabetic nephropathy. Acta Diabetol. 2014 Dec;51(6):905-15. doi:10.1007/ s00592-014-0650-7.

12. Yasui J, Kawasaki E, Tanaka S, et al; Japan Diabetes Society Committee on Type 1 Diabetes Mellitus Research. Clinical and Genetic Characteristics of Non-Insulin-Requiring Glutamic Acid Decarboxylase (GAD) Autoantibody-Positive Diabetes: A Nationwide Survey in Japan. PLoS One. 2016 May 13;11(5):e0155643. doi:10.1371/journal.pone.0155643.

13. Shahbazian H, Rezaii I. Diabetic kidney disease; review of the current knowledge. J Renal Inj Prev. 2013 Jun 1;2(2):73-80. doi:10.12861/jrip.2013.24.

14. Kim MK. Treatment of diabetic kidney disease: current and future targets. Korean J Intern Med. 2017 Jul;32(4):622-630. doi:10.3904/kjim.2016.219.

15. Levey AS, Inker LA, Coresh J. GFR estimation: from physiology to public health. Am J Kidney Dis. 2014 May;63(5):820-34. doi:10.1053/j.ajkd.2013.12.006.

16. American Diabetes Association. 11. Microvascular Complications and Foot Care: Standards of Medical Care in Diabetes-2021. 
Diabetes Care. 2021 Jan;44(Suppl 1):S151-S167. doi:10.2337/ dc21-S011.

17. Fadiga L, Saraiva J, Catarino D, Frade J, Melo M, Paiva I. Adult-onset autoimmune diabetes: comparative analysis of classical and latent presentation. Diabetol Metab Syndr. 2020 Dec 3;12(1):107. doi:10.1186/s13098-020-00616-1.

18. Carlsson S. Environmental (Lifestyle) Risk Factors for LADA. Curr Diabetes Rev. 2019;15(3):178-187. doi:10.2174/15733 99814666180716150253.

19. Pugliese G, Penno G, Natali A, et al; Italian Diabetes Society and the Italian Society of Nephrology. Diabetic kidney disease: New clinical and therapeutic issues. Joint position statement of the Italian Diabetes Society and the Italian Society of Nephrology on "The natural history of diabetic kidney disease and treatment of hyperglycemia in patients with type 2 diabetes and impaired renal function". Nutr Metab Cardiovasc Dis. 2019 Nov;29(11):1127-1150. doi:10.1016/j.numecd.2019.07.017.

20. Ekinci EI, Jerums G, Skene A, et al. Renal structure in normoalbuminuric and albuminuric patients with type 2 diabetes and impaired renal function. Diabetes Care. 2013 Nov;36(11):3620-6. doi:10.2337/dc12-2572.

21. Sulaiman MK. Diabetic nephropathy: recent advances in pathophysiology and challenges in dietary management. Diabetol Metab Syndr. 2019 Jan 23;11:7. doi:10.1186/s13098-019-0403-4.

Received 11.01.2021

Revised 01.02.2021 Accepted 16.02.2021

\section{Information about authors}

Iryna Tsaryk, MD, PhD student at the Department of Clinical Immunology, Allergology and Endocrinology, Bukovinian State Medical University, Chernivtsi, Ukraine; e-mail: irynatsaryk13@gmail.com; contact phone: +38 (099) 4427694.

Nataliia Pashkovska, MD, PhD, DSc, Professor, Head of the Department of Clinical Immunology, Allergology and Endocrinology, Bukovinian State Medical University, Chernivtsi, Ukraine; e-mail: nvpashkovska@gmail.com; contact phone: +38 (050) 66045 54; https://orcid.org/0000-0002-9896-1744.

Conflicts of interests. Authors declare the absence of any conflicts of interests and their own financial interest that might be construed to influence the results or interpretation of their manuscript.

Царик I.О., Пашковська Н.В.

Буковинський Аержавний медичний університет, м. Чернівці, Україна

\section{Особливості перебігу Аіабетичної хвороби нирок у хворих на ^атентний वвтоімунний Аіабет Аорослих}

Резюме. Актуальність. Латентний автоімунний діабет дорослих (LADA) є гетерогенним типом цукрового діабету (ЦД), що поєднує ознаки цукрового діабету 1-го (ЦД1) та 2-го типу (ЦД2). Дані щодо частоти і структури мікросудинних ускладнень при LADA малочисельні й доволі суперечливі, практично відсутня інформація про особливості їх перебігу, що вказує на необхідність проведення досліджень у цьому напрямку. Мета дослідження: з'ясувати особливості перебігу діабетичної хвороби нирок у хворих на латентний автоімунний діабет дорослих порівняно з класичними типами цукрового діабету. Матеріали та методи. Обстежено 112 хворих на ЦД із діабетичною хворобою нирок (ДХН). Пацієнтів розподілили на три групи: I - 54 особи з LADA, II - 30 хворих на ЦД1, III - 28 пацієнтів із ЦД2. Особливості перебігу ДХН вивчали на підставі оцінки даних анамнезу, клінічного обстеження, значень швидкості клубочкової фільтрації (ШКФ), альбумінурії, відношення альбуміну до креатиніну в сечі. Результати. За даними анамнезу діагноз ДХН у пацієнтів із LADA встановлювався в середньому через 3 роки після маніфестації ЦД, при цьому на 4,5 року раніше, ніж при ЦД1, але на 1,3 року пізніше, ніж при ЦД2. Аналіз показників ШКФ показав, що при LADA найбільш часто (у $63 \%$ пацієнтів) реєструвалась категорія G3 (G3a - у $46 \%$, G3b - у $17 \%$ пацієнтів). Решта обстежених мали категорію G1 (7 \%), G2 (24\%), і тільки в 6 \% пацієнтів виявлено стадію G4. У пацієнтів усіх груп переважали категорії альбумінурії A1 та A2 (при LADA - по $43 \%$ осіб у кожній категоріі), водночас категорія A3 при LADA реєструвалась удвічі частіше, ніж при ЦД1. При LADA переважаючими фенотипами ДХН були неальбумінурійне порушення функції нирок (НАПН) (43\%) і альбумінурійний фенотип (АФ) (35\%), при ЦД1 - АФ (50\%) і НАПН (40\%), а при ЦД2 усі три фенотипи реєструвалися майже з однаковою частотою (АФ - у $32 \%$, НАПН - у $29 \%$ пацієнтів, прогресуюче зниження функції нирок - у 39 \% хворих). Висновки. Перебіг діабетичної хвороби нирок в осіб із латентним автоімунним діабетом дорослих відрізняється від такого при класичних типах цукрового діабету, що вказує на необхідність розробки специфічного алгоритму ведення цієї категорії пацієнтів.

Ключові слова: цукровий діабет; латентний автоімунний діабет дорослих; діабетична хвороба нирок 